7. Widmark.- "Ueber den Musculus Dilatator Pupillae des Menschen." Mitteil. a. d. Carol. Medico-Chirurg. Inst. in Stockholm, Heft. 3, 1901.

8. Szily.- " Beiträge zur Kenntniss der Anatomie und Entwickelungsgeschichte der hinteren Irisschichten." Arch.f. Ophthal., Bd. LIII, p. 459, 1902.

9. Herzog.- "Ueber die Entwickelung der Binnenmuskulatur des Auges." Arch. f. mikroskop. Anatomie, Bd. LX, 1902.

10. Treacher Collins, E., and Mayou, M. Stephen.- " Pathology and Bacteriology in Ophthalmic Practice," pp. 64 and 82, 1911.

11. Salzmann. - "Anatomie und Histologie des menschlichen Augapfels im Normalzustande," Taf. VIII, 2, Vienna, 1912.

12. Rauber-Kopsch.- "Die Anatomie des Menschen," Sinnesorgane, Aufl. X., Abt. 6, fig. 135, Leipzig, 1916.

13. Merkel.- "Die Anatomie des Menschen." Atlas zur fünften Abteiluug, fig. 107, Wiesbaden, 1917.

14. American Encyclopedia and Dictionary of Ophthalmology. Vol. X, p. 10673,, 1914-1921.

15. Holth, S., and Berner, O.-“"Miosis congenita-ex-aplasia Musculi Dilatatoris Pupillae." Forhandlinger $i$ Det medicinske Selskap i Kristiania, pp. 63-69, 23de Februar, 1921. Norsk. Magazin f. Laegevidensk, September, 1921.

16. Holth, S., and Berner. O.- "Miosis congenita seu Microcoria familiaris-ex-Aplasia Musculi Dilatatoris Pupillae," with 3 plates and 3 figures in the text. Videnskapsselskapets Skrifter, I. Mat.-Naturv. Klasse, 1922, No. t. (In commission by Jacob Dybwad, Kristiania, 1922.)

17. Kurt Saupe.- "Ueber einen Fall von angeborenem Fehlen des Musculus Dilatator Pupillae selbst oder seiner Innervierung." Klin. Monatsbl. $f$. Augenheilk.., Bd. LXVIII, pp. 464-471, April-Mai, 1922. (Without microscopical examination.)

18. Holth, S., and Berner, O.- " Another Case of Congenital Miosis or Pinhole Pupils Anatomically Examined Videnskapsselskapets Skrifter, I. Mat.-Naturv. Klasse, 1923. In commission by Jacob Dybwad, Kristiania, 1923. Read at Det medicinske Selskap i Kristiania, February 21, 1923.

\title{
BINOCULAR CHOROIDAL TUBERCULOSIS WITH DETACHMENT OF THE RETINA IN TWO KITTENS.* ADDENDUM
}

BY

\section{J. B. 'Lawford and Humphrey neame \\ LONDON}

DR. STANLEy GRIffiths reports on his bacteriological investigation of specimens from the second kitten as follows :-

"An emulsion of the mesenteric gland produced general tuberculosis in a rabbit, and cultures obtained from the lesions of the cat were typically bovine in cultural characteristics.

"Undoubtedly the infecting tubercle bacilli are bovine in type."

*.See British Journal of Ophthalmólogy, July, 1923, p. 305. 